\title{
The effect of supply agility mediation through the relationship between trust and commitment on supply chain performance
}

\author{
Moh. Mukhsin ${ }^{a^{*}}$ and Tulus Suryanto ${ }^{\mathrm{b}}$
}

${ }^{a}$ Faculty of Economics and Business, Universitas Sultan Ageng Tirtayasa, Banten, Indonesia

${ }^{b}$ Faculty of Islamic Economic and Business, Universitas Islam Negeri (UIN) Raden Intan Lampung, Indonesia

\section{H R O N I C L E}

\section{Article history:}

Received February 29, 2021

Received in revised format May

20, 2021

Accepted June 92021

Available online

June 92021

Keywords:

Trust

Commitment

Supply agility

Supply chain performance \begin{abstract}
A B S T R A C T
This study examines the mediating effect of supply agility on the relationship between trust and commitment and supply chain performance. The study examines the direct effect of trust and commitment on supply chain performance, trust and commitment on supply agility and supply agility on supply chain performance. The study also examines the indirect effect of trust and commitment on supply chain performance with supply agility as an intervening variable. The research sample consists of 100 respondents who sell chicken meat in seven districts in Lebak Regency, Banten Province, Indonesia. Data are collected using purposive sampling technique. The statistical tool used is the SmartPLS 3.0 application. The results of this study indicate that; trust has no effect on supply chain performance, commitment has a significant effect on supply chain performance, trust has a significant effect on supply agility, commitment has a significant effect on supply agility, and supply agility has a significant effect on supply chain performance.
\end{abstract}

(C) 2021 Growing Science Ltd. All rights reserved.

\section{Introduction}

The relationship between suppliers, companies and consumers must be managed properly. How to make suppliers take responsibility for product quality, long-term relationships, and distribution from upstream to downstream in a timely manner. The supply agility dimension is the system's ability to respond to change. From their perspective they simplify the process more so that it can be more agile. This line of reasoning is based on previous literature alluding to the relationship between agility and complexity (Balaji, Velmurugan, \& Subashree, 2015). Emphasized that further research is needed to identify strategic antecedents of supply chain agility level. In particular it is called for future research to investigate the role of market orientation and supply chain orientation in achieving supply chain agility (Gligor, Holcomb, \& Feizabadi, 2016).Awareness of the importance of supply chain management as a 'set of beliefs' for individuals in the organization, and encouraging the creation of supply chain-based activities which then produce outputs that reflect the linkages between entities / companies in the supply chain. Researchers have mixed views on how the relationship between small and medium enterprises affects operational performance in the supply chain, which can determine success in the service, manufacturing, and retail industries.(Airport, Leckie, Lobo, \& Hewege, 2017).Nowadays it is increasingly important for small and medium enterprises to strategize managing buyer and supplier relationships to provide final value to customers. If the relationships developed with supply chain partners are beneficial and result in different operational performance compared to competitors, a competitive advantage can be generated, but it is also important to assess whether the benefits generated are sustainable or not (Nyaga \& Whipple, 2011). Some studies argue that trust and commitment fully fulfill an important aspect of the supplier and retailer relationship (Sun, Liu, \& Yang, 2018). According to Kwon and Suh (2004), the success of supply chain performance stems from the value of trust and strong commitment between partners in the supply chain. Vice versa, low levels of trust and commitment can be a factor in the possibility of low performance of the supply chain (Mukhsin, 2020). Meyer et al. (2017) stated that supply chain agility has been widely accepted as an important aspect for successful organizations, * Corresponding author

E-mail address: _muksinuntirta@gmail.com (M. Mukhsin)

(C) 2021 Growing Science Ltd. All rights reserved.

doi: $10.5267 /$ j.uscm.2021.6.006 
however, given this fact agility has not been well defined in the literature and there is only limited literature available adding to the fact that it is characterized by ambiguity. Meyer et al. (2017) support this because they argue that supply chain agility is the key to adapting to market variations more efficiently, reducing inventory, enabling rapid customer response, and integrating with suppliers more effectively. By applying trust and commitment in the supply chain, small and medium enterprises will get many advantages that can be useful for the sustainability of their business. Making a good strategy by maintaining the supply chain with suppliers and consumers. However, in practice, there are still many business actors who do not collaborate with suppliers so that small and medium enterprises cannot benefit from the performance of a closely-knit supply chain. This can be seen from the number of business actors who purchase raw materials in the market rather than directly from suppliers. Lebak Regency is an area with great potential in the development of livestock agribusiness. Lebak Regency is one of the biggest chicken producer areas in Banten. which can supply 4 million chickens. With an adequate supply of chicken meat, this problem should be resolved with a better distribution. This is part of the agility that partners should build. Data on chicken meat production in 2016 were $96.554,000$, in 2017 as many as $73,488,060$, in 2019 as many as $87,216,620$, in 2020 as many as 108,228,000. Based on the chicken meat production data, there is an increase in the supply of chicken meat in Banten Province, especially from 2019 and 2020 which has increased significantly. This condition should be able to meet the demand for chicken meat, especially in Lebak Regency which is an area with a high level of production and has the potential to become a supply area for chicken meat to several areas in Banten Province. Under these conditions, both suppliers and retailers should collaborate to be able to manage the distribution system so that chicken can be distributed properly and ensure the availability of chicken meat to meet customer needs. Other than that, building trust and commitment is an important aspect so that the cooperative relationship between suppliers and sellers of chicken meat can run well. These things are done with the aim of increasing efficiency and effectiveness in the supply chain which in turn can improve supply chain performance.

This study was conducted because previous studies examined trust and commitment to supply chain performance so that in this study a new intervening variable was introduced, namely supply agility. There are still differences in the results of research regarding Trust in supply chain performance, find it is positive relationship (Hidayat et al., 2015; Wu et al., 2012; Ezgi Şahin et al., 2017; Capaldo \& Giannoccaro, 2015; Dubey et al., 2020; Shin, Thai, \& Yuen, 2018), while obeying (Ezgi Şahin et al., 2017), confidence in supply chain performance is positive but insignificant. According to research results (Dubey et al., 2020; Ezgi Şahin et al., 2017), commitment has a significant positive effect, while according to Ezgi Şahin et al. (2017) and Shin et al. (2018), commitment has a negative effect on the supply chain.

\section{Theoretical review}

\subsection{Supply Chain Performance}

Ballou et al. (2007) stated that the supply chain is all activities related to the flow of transformation of goods from the raw material stage to the end user, as well as the flow of information(IG Kwon, Louis, \& Louis, 2004)said the success of supply performance comes from the high value of trust and strong commitment between partners in supply performance. In a supply performance system, the partnership process is defined as the interaction between commitment, trust and collaboration (Mukhsin, 2020). Supply chain performance is the level of the supply chain's ability to maximize the chain network and improve the competitiveness of supply chain actors by considering key supply chain performance indicators (Wibowo et al., 2017).

\subsection{Supply Agility}

Supply Agility is an operational strategy that focuses on driving speed and flexibility in the supply chain (Balaji et al., 2015). Supply agility is the supply chain's ability to respond to market changes in order to maintain competitiveness (Mulyati, 2020). According to Meyer et al. (2017), supply agility is an emerging dynamic capability that is essential in today's business environment Wilding et al. (2014) view agility as one of the most important issues in contemporary supply chain management. The theoretical basis for supply chain agility is underdeveloped, because agility is a complex concept consisting of many elements (Gligor et al., 2016). Agility in the supply chain is the ability to respond to requests quickly. Agility in the supply chain is needed to be able to deal with changes in supply and demand, so that companies can remain competitive and have shorter life cycles so that companies must continue to develop themselves and create new products and services. Agility includes different concepts which include: (1) flexibility, (2) alertness, (3) speed, (4) assertiveness and (5) accessibility (Wilding et al., 2014). Flexibility and mindfulness have become the most influential concepts associated with agility as they play the most important roles in its success (Çağlar Kalkan \& Aydın, 2020). While several agility characteristics have been identified. According to Swafford, Ghosh, \& Murthy, to determine supply agility, four indicators are needed that can help determine supply agility, namely cycle time, lead time, customer service level, and market responsiveness (Hendricks, Singhal, \& Stratman, 2007).

\subsection{Trust}

Moorman and Miner state that trust is the desire to trust a trading partner, who is considered reliable. Doney and Cannon define trust as the credibility and goodwill of cognitive targets, they also argue that trust comes from the nature of honesty 
with one another (Xiao et al., 2010). Andersen and Narus describe trust as a belief by a company that its exchanging partners will stay away from actions that create positive results for all partners involved (Civelek \& Çemberci, 2020). Trust in the supply chain operates as an informal facilitator between organizations. When each member of the supply chain trusts each other, it will provide the best for the interests of the entire supply chain, even though it can be detrimental to them. Conversely, when members of the supply chain do not have trust, they will tend not to collaborate when it leads to losses. Under such circumstances, partnering companies are likely to agree to collaborate to improve overall system performance only if it does not hurt their local performance (Capaldo \& Giannoccaro, 2015). In Kotler \& Keller's (2006) research, there are four indicators of trust, namely, transparency, mutual openness, honesty, and fulfillment of expectations. Meanwhile, according to Mellani et al. (2019) and Sánchez and Pérez (2005), four indicators of trust consist of providing information, compensation, security guarantees and guarantees of confidentiality. In research accomplished by Savira and Suharsono (2013), in measuring the trust variable, there were five indicators used, namely openness, confidence, honesty, responsibility, and providing information. The five indicators of trust are open communication, sharing information, experience, honesty, and responsibility.

\subsection{Commitment}

Ryu et al. (2009) explain if the commitment from the supply chain partners will increase cooperative activities. Also explain if the commitment will facilitate informative transactions and also help avoid problems between supply chains (Kim \& Chai, 2017). Developing a trustworthy business relationship may require a long-term process, which takes place step by step, the risk and uncertainty is reduced, while the commitment and trust itself will increase (IWG Kwon \& Suh, 2004). Anderson and Weitz explain that a desire to develop stable relationships, a willingness to make short-term sacrifices, and a belief in relationship stability indicate commitment. According to Wetzels et al. (1998), in general, there are two types of commitment: affective commitment and calculative commitment. Sánchez and Pérez (2005) explained that affective commitment is a company's tendency to maintain relationships, emotional ties, and goodwill towards partners. Conversely, according to Wetzels et al. (1998), Calculative commitment can force a company to maintain relationships that are against its will, resulting in an unstable relationship, which can dissolve as soon as opportunities arise (Yuan, Feng, Lai, \& Collins, 2018). In Sugiarto's research, he explained that there are four indicators used to measure commitment, namely affective, continuous, normative, and belief. Meanwhile, according to Lee et al. (2018), there are three indicators of commitment, namely a strong desire to survive, a feeling of involvement in the company's goals, and emotional attachment. According to Sari et al. (2018), there are four indicators to measure commitment, namely loyalty, attachment, feelings of happiness, and a sense of belonging.

\section{Research Methods}

The research used is quantitative research. Quantitative research is methods for testing certain theories by examining between variables. These variables are measured so that data consisting of numbers can be analyzed according to statistical procedures (UK Home Office, 2015). The data used in this research are primary and secondary data. Primary data is data obtained directly by researchers to answer research questions. Primary data collected is data on respondent characteristics and all questionnaire answers regarding trust, commitment, supply agility and supply chain performance. All primary data were obtained from members of the supply chain. While secondary data is data obtained and collected based on the results of literature studies. The secondary data needed is data related to supply chain partners.

\subsection{Population and Sample}

The population in this study were chicken meat sellers in Lebak Regency, Banten Province. The sample in this study used a purposive sampling method, the sample of this study was chicken meat sellers in Lebak Regency, Banten Province, Indonesia. The highest number of questionnaires was in Maja District with a total of 21 questionnaires and a percentage of $21 \%$. Furthermore, Rangkasbitung District had 18 questionnaires with a percentage of $18 \%$, Warunggunung District with 16 questionnaires with a percentage of 16\%, Malingping District with 13 questionnaires with a percentage of 13\%. Then Sajira District with 12 questionnaires with a percentage of 12\%, and Cipanas District with 11 questionnaires with a percentage of $11 \%$.

\section{Measurement Model}

Validity Test According to Md Ghazali (2016), the validity test was conducted to determine how the ability of research instruments to measure what should be measured. This model test is used to validate the research model that was built by testing the validity of the construct consisting of convergent validity and discriminant validity (Sari et al., 2018).

\subsection{Construct Validity Test}

The construct validity test in general can be measured using the loading score parameter in the research model (Rule of Thumbs $>0.7$ ) and using the AVE (Average Variance Extracted) parameter with a score $>0.5$, Communality $>0.5$, and $\mathrm{R}^{2}$ and Redundancy. If the loading score is $<0.5$, then this indicator can be removed from its construct because this indicator is not loaded into the construct that represents it. However, if the loading score is between 0.5 to 0.7 , then the indicator should not 
need to be removed if it has a loading score as long as the AVE and Communality indicators are $>0.5$ (Sari et al., 2018).

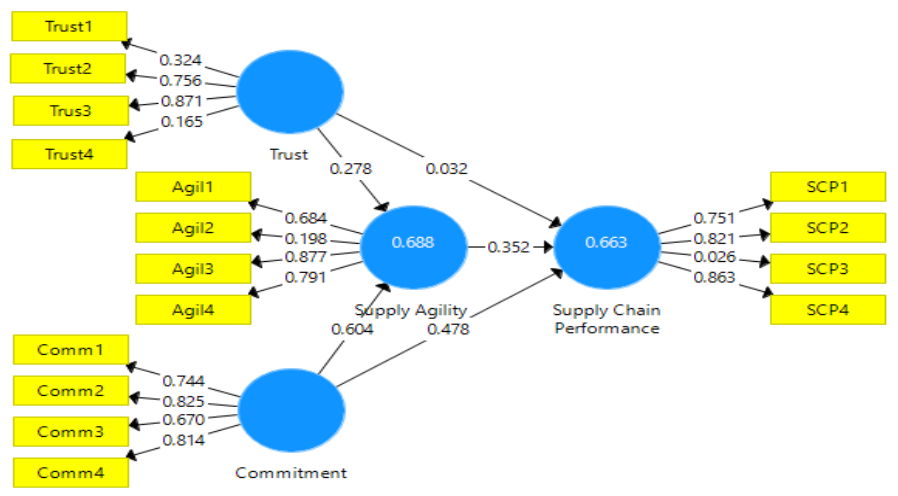

Fig. 1. Partial Least Square Structural Model 1

After removing the indicator with a loading score $<0.7$, it is necessary to retest it. The following is the result of retesting the construct validity.

\subsection{Convergent Validity Test}

Convergent validity test parameters can be seen from the AVE (Average Variance Extracted) score which must be above 0.5 . This means that the likelihood of an indicator in a construct entering another variable is lower so that the likelihood of the indicator converging and entering the construct in question is greater, which is above 50\%.(Sari et al., 2018).

Table 1

Loading Scores

\begin{tabular}{|c|c|c|c|c|}
\hline Construct & Trust & Commitment & Supply Agility & Supply Chain \\
\hline Trust 2 & 0.772 & & & \\
\hline Trust 3 & 0.888 & & & \\
\hline Comm_1 & & 0.795 & & \\
\hline Comm_2 & & 0.835 & & \\
\hline Comm_4 & & 0.872 & & \\
\hline Supply Agil_3 & & & 0.909 & \\
\hline Supply Agil_4 & & & 0.862 & \\
\hline SCP_1 & & & & 0,738 \\
\hline $\mathrm{SCP}_{2}^{-} 2$ & & & & 0.825 \\
\hline $\mathrm{SCP}_{4}$ & & & & 0.870 \\
\hline
\end{tabular}

Sources: Primary data is processed (2021)

Based on the results of the SmartPLS processing listed in the table above, it can be concluded that the Trust_2 and Trust_3 indicators can be declared valid because they have a loading score $>0.7$ with AVE $>0.7$. It can be concluded that the two indicators are able to measure the trust construct. The Comm1, Comm2, and Comm 4 indicators can be declared valid because they have a loading score $>0.7$ with $\mathrm{AVE}>0.7$. It can be concluded that the three indicators are able to measure the Commitment construct. Indicators for Supply Agil_3, and Supply Agil_4 can be declared valid because they have a loading score of $>0.7$ with AVE $>0.7$. It can be concluded that the two indicators are able to measure the supply agility construct. Indicators SCP_1, SCP_2, and SCP_ 4 can be declared valid because they have a loading score $>0.7$ with AVE $>0.7$.

Table 2

Convergent Validity Test

\begin{tabular}{lc}
\hline Construct & AVE \\
\hline Trust & 0.693 \\
Commitment & 0.697 \\
Supply Agility & 0.784 \\
Supply Chain Performance & 0.661 \\
\hline
\end{tabular}

Sources: Primary data is processed (2021)

\subsection{Reliability Test}

Reliability test can be seen from the value of composite reliability, which is a statistical technique used to measure internal consistency in instrument reliability tests or psychometric data. Composite reliability measures the real reliability value of a variable. A construct can be said to be reliable if the composite reliability value is $>0.7$ (Anuraga, Sulistiyawan, \& Munadhiroh, 2017). 
Table 3

Reliability Test

\begin{tabular}{lc}
\hline Construct & AVE \\
\hline Trust & 0.818 \\
Commitment & 0.873 \\
Supply Agility & 0.879 \\
Supply Chain Performance & 0.853 \\
\hline Sources: Primary data is processed (2021) & \\
\hline
\end{tabular}

Sources: Primary data is processed (2021)

Based on the reliability test table, which is the result of the measurement model, the composite reliability of each construct is $>0.7$, so it can be concluded that the measuring instrument used in this study is reliable, which means that the measuring instrument in this study shows the accuracy, consistency, and accuracy of the tool. measure in taking measurements.

\subsection{Structural Model (Inner Model)}

Structural models in PLS are evaluated using $\mathrm{R}^{2}$ for dependent constructs, path coefficient values or t-values for each path to test the significance between constructs in the structural model. The path coefficient value or inner model shows the level of significance in testing the hypothesis(Anuraga et al., 2017). The following is a structural model in this study.

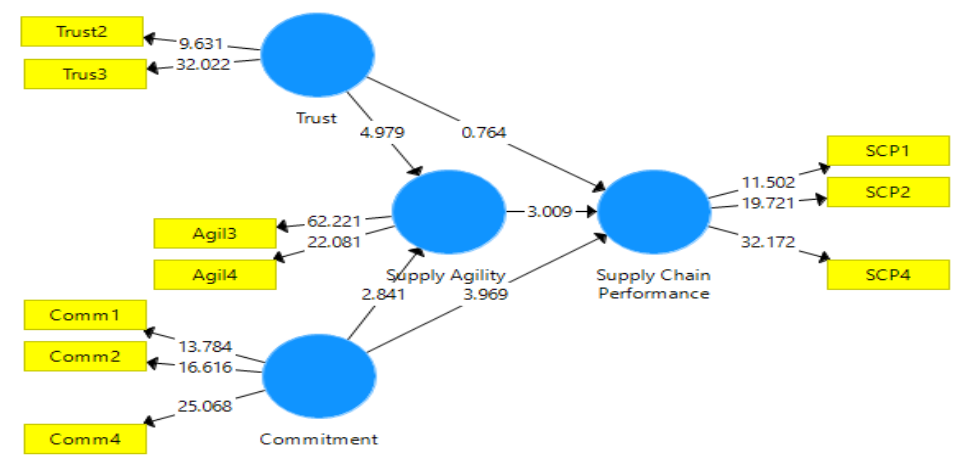

Table 4

Fig. 2. Partial Least Square Structural Model 2

Test Result

\begin{tabular}{lc}
\hline Construct & R Square \\
\hline Supply Agility & 0.584 \\
Supply Chain Performance & 0.663
\end{tabular}

Sources: Primary data is processed (2021)

Based on Table 4, the $\mathrm{R}^{2}$ value of supply agility is 0.584 which means that the variation in change in supply agility which is influenced by the trust and commitment variables is $58.4 \%$ and the variation in the change in supply agility which is influenced by other variables is $41.6 \%$. While the $\mathrm{R} 2$ value of supply chain performance is 0.663 which means that the variation of changes in supply chain performance that is influenced by the variables of trust, commitment and supply agility is $66.3 \%$ and the variation in changes in supply chain performance influenced by other variables is $33.7 \%$.

Table 5

Hypothesis Test Results

\begin{tabular}{lccc}
\hline Direct Influence & Original Sample & TStatistic & PValues \\
\hline Supply Agility $\rightarrow$ Supply Chain & 0.395 & 3.009 & 0.002 \\
Commitment $\rightarrow$ Supply Agility & 0.335 & 2.841 & 0.003 \\
Commitment $\rightarrow$ Supply Chain & 0.426 & 4.066 & Accepted \\
Trust $\rightarrow$ Supply Agility & 0.516 & 4.979 & Accepted \\
Trust $\rightarrow$ Supply Chain Performance & 0.095 & 0.764 & 0.000 \\
\hline
\end{tabular}

Sources: Primary data is processed (2021)

1. Based on the data shown in Table 5 , the coefficient of supply agility parameter to supply chain performance is 0.395 , which means that each increase in supply agility is 1 (one) point, it will increase supply chain performance by 0.395 points. A positive parameter coefficient indicates that supply agility and supply chain performance have a unidirectional relationship. Hypothesis test results also show that the value of t-count $(3.009)>$ t-table $(1.991)$ and a significance value $(0.002)<0.05$ indicates that supply agility has a significant effect on supply chain performance. The results of this study are in accordance with the research (Capaldo \& Giannoccaro, 2015), which states that supply agility can have a positive effect on supply chain performance. Trust is the foundation of business. Building trust in long-term relationships with partners is an important factor in creating customer loyalty. This trust cannot just be recognized by other parties / business partners but must be built from scratch and can be proven. Success in the company's performance in supply performance comes from the high value of trust 
and strong commitment between relationships in supply performance (IG Kwon, Louis, \& Louis, 2004). Sutanto and Kurniawan (2016) revealed that when trust is present, members of the supply chain will seek to work on each other's differences for the benefit of all members (Nyaga \& Whipple, 2011). Ryu et al. (2009) believe that trust is very important in building commitment. Companies that believe in the integrity of their partners will have a higher intention to continue working with these partners (Zhong, Xu, \& Wang, 2017).

2. Based on the data shown in Table 5 , the commitment parameter coefficient to supply agility is 0.335 , which means that each increase in commitment is 1 (one) point, it will increase supply agility by 0.335 points. The positive parameter coefficient indicates that commitment to supply agility has a unidirectional relationship. Hypothesis test results also show that the value of t-count $(2.441)>$ t-table $(1.990)$ and a significance value $(0.003)<0.05$ indicates that commitment has a significant effect on supply agility. With these results, it can be stated that $\mathrm{H} 2$ is accepted. The higher the commitment between partners in providing raw materials, the higher the agility of the existing supply. In line with research results (Balaji et al., 2015)test commitment to supply agility. The results of this research commitment influence supply performance. The higher the commitment that is built on satisfaction and trust, the higher the quality of the supply performance relationship (Mukhsin, 2020). According to Ismail et al. (2017), a long term relationship requires commitment from the parties involved. This argument is also supported (Nyaga \& Whipple, 2011). Commitments from supply chain partners will enhance collaborative activities and facilitate informative transactions (Ryu et al., 2009) The higher the commitment that is built on satisfaction and trust, the higher the relationship between the supplier and the company.

3. Based on the data shown in Table 5, the coefficient of commitment parameters to supply chain performance is 0.426 , which means that each increase in commitment is 1 (one) point, it will increase supply chain performance by 0.426 points. Positive parameter coefficients indicate that commitment to supply chain performance has a unidirectional relationship. Hypothesis test results also show that the value of t-count $(4.066)>$ t-table $(1.991)$ and the significance value $(0.000)<0.05$ indicates that commitment has a significant effect on supply chain performance. With these results, it can be stated that H3 is accepted. The results of this study are in accordance with the research(Dubey et al., 2020)which states that commitment can have a positive effect on supply chain performance. Dyer \& Chu argues that trust is considered to be fundamental to collaborating effectively in implementing supply chains and has been found to be the main reason behind successful supply chains (Civelek \& Çemberci, 2020). Supply agility is a key element needed for supply chains to survive in an uncertain environment when the supply chain management situation is at risk (Ezgi Şahin et al., 2017). Supply agility helps companies deliver the right product at the right time (Ghatari et al., 2013). According to Wilding et al. (2014) Supply chain agility aids in enhancing customersupplier relationships with trust as the key to sustainability. It is also important for companies to gain a competitive advantage.

4. Based on the data shown in Table 5, the coefficient of the confidence parameter on supply agility is 0.516 , which means that every 1 (one) point increase in confidence will increase supply agility by 0.516 points. A positive parameter coefficient indicates that trust with supply agility has a unidirectional relationship. Hypothesis test results also show that the t-value $(4.979)>$ t-table $(1.990)$ and the significance value $(0.000)<0.05$ indicates that trust has a significant effect on supply agility. With these results, it can be stated that $\mathrm{H} 4$ is accepted. In line with research results(Balaji et al., 2015). Wilding et al. (2014) argue that supply agility can quickly fulfill customer orders, can introduce new products in a timely manner, and can quickly move in and out of the strategic alliances of its mutually committed trading partners. (Costantino, Dotoli, Falagario, Fanti, \& Mangini, 2012)defines supply chain agility as a network of independent organizations, integrated and interconnected with efficient financial, information and material flows while focusing on performance and flexibility. Commitment is defined as the perception of the procurement / purchasing part of the supplier's confidence regarding the existing cooperative relationship, as well as the maximum efforts of the supplier to maintain the partnership relationship (AMBE, 2010).

5. Based on the data shown in Table 5, the coefficient of confidence parameters on supply chain performance is 0.619 , which means that each increase in confidence is 1 (one) point, it will increase supply chain performance by 0.095 points. Positive parameter coefficients indicate that trust with supply chain performance has a unidirectional relationship. Hypothesis test results also show that the value of t-count (0.821) $<$ t-table (1.991) and a significance value $(0.412)>0.05$ indicates that trust has no effect on supply chain performance. With these results, it can be stated that H5 is rejected. This is in line with the research results(Ezgi Şahin et al., 2017; Capaldo \& Giannoccaro, 2015), that belief has a positive but not significant effect, this is contrary to the results of the study (Hidayat et al., 2015; Wu et al., 2012; Ezgi Şahin et al., 2017), that trust has a positive and significant effect on supply chain performance. Based on the results of SmartPLS processing which have been shown in table 6 , it shows the indirect influence between the variables of trust, commitment, on supply chain performance which is mediated by supply agility.

Table 6

Hypothesis Test Results

\begin{tabular}{lcc}
\hline Indirect Influence & Original Sample & T-Statistic \\
\hline Trust $\rightarrow$ Supply Chain PerformancePerformance & 0.204 & 2,344 \\
Commitment $\rightarrow$ Supply Chain & 0.132 & 2,344 \\
\hline
\end{tabular}

Sources: Primary data is processed (2021)

The coefficient of confidence parameters on supply chain performance mediated by supply agility is 0.204 , which means that every 1 (one) point increase in confidence will increase supply chain performance by 0.204 points. Positive parameter coefficients indicate that trust with supply chain performance has a unidirectional relationship. Hypothesis test results also 
show that the t-value $(2.344)<t$-table $(1.991)$ and the significance value $(0.019)<0.05$ indicate that supply agility can mediate confidence in supply chain performance. Meanwhile, the parameter coefficient of commitment to supply chain performance mediated by supply agility is 0.132 , which means that every 1 (one) point increase in confidence will reduce supply chain performance by 0.132 points. A positive parameter coefficient indicates that commitment to supply chain performance has a non-unidirectional relationship. Hypothesis test results also show that the value of $\mathrm{t}$-count $(2.344)<\mathrm{t}$-table $(1.991)$ and a significance value $(0.024)<0.05$ indicates that supply agility can mediate commitment to supply chain performance. Based on the above results supply agility does not mediate trust and commitment to supply chain performance.

\section{Conclusion}

Based on the research results regarding the effect of trust and commitment on supply performance with supply agility as an intervening variable with the following conclusions: Trust among supply chain members is not able to encourage better supply chain performance, but good trust can lead to better supply agility. Trust variables also have a significant influence on supply chain performance through supply agility. The indirect effect of the variable trust through supply agility is greater than the direct effect in increasing supply chain performance. The higher the commitment among the members of the supply chain, it can lead to better supply chain performance, a good commitment can lead to better supply agility. The commitment variable also has a significant influence on supply chain performance through supply agility. The indirect effect of variable commitment through supply agility is greater than the direct effect in increasing supply chain performance.

\section{References}

Airport, S., Leckie, C., Lobo, A., \& Hewege, C. (2017). Power and relationship quality in supply chains: The case of the Australian organic fruit and vegetable industry. Asia Pacific Journal of Marketing and Logistics, 29(3), 501-518.

AMBE, IM (2010). Agile Supply Chain: Strategy for Competitive Advantage. Journal of Global Strategic Management, 1(4), 5-5. https://doi.org/10.20460/jgsm.2010415835

Anuraga, G., Sulistiyawan, E., \& Munadhiroh, S. (2017). Structural Equation Modeling - PLS for East Java IPKM Modeling. 257-263.

Balaji, M., Velmurugan, V., \& Subashree, C. (2015). TADS: An assessment methodology for agile supply chains. Journal of Applied Research and Technology, 13(5), 504-509. https://doi.org/10.1016/j.jart.2015.10.002

Ballou, R. H. (2007). The evolution and future of logistics and supply chain management. European Business Review, 19(4).

Çağlar Kalkan, MB, \& Aydın, K. (2020). The role of 4PL provider as a mediation and supply chain agility. Modern Supply Chain Research and Applications, 2(2), 99-111. https://doi.org/10.1108/mscra-09-2019-0019

Capaldo, A., \& Giannoccaro, I. (2015). How does trust affect performance in the supply chain? the moderating role of interdependence. International Journal of Production Economics, 166, 36-49. https://doi.org/10.1016/j.ijpe.2015.04.008

Civelek, ME, \& Çemberci, M. (2020). The Effects of Trust and Capability in Supply Chain on Firm Performance through Supply Chain Agility and Collaborative Advantage. Journal of Business Research - Turk, 12(1), 440-453.

Costantino, N., Dotoli, M., Falagario, M., Fanti, MP, \& Mangini, AM (2012). A model for supply management of agile manufacturing supply chains. International Journal of Production Economics, 135(1), 451-457.

Dubey, R., Bryde, D.J., Foropon, C., Graham, G., Giannakis, M., \& Mishra, D.B. (2020). Agility in humanitarian supply chain: an organizational information processing perspective and relational view. Annals of Operations Research. https://doi.org/10.1007/s10479-020-03824-0

Ezgi Şahin, Murat Çemberci, Mustafa Emre Civelek, \& Nagehan Uca. (2017). The Role of Agility in the Effect of Trust in Supply Chain on Firm Performance. Management Studies, 5(4). https://doi.org/10.17265/2328-2185/2017.04.008

Ghatari, A.R., Mehralian, G., Zarenezhad, F., \& Rasekh, H. (2013). Developing a model for agile supply: An empirical study from Iranian pharmaceutical supply chain. Iranian Journal of Pharmaceutical Research, 12(SUPPL.), 189-201. https://doi.org/10.22037/ijpr.2013.1287

Gligor, D.M., Holcomb, M.C., \& Feizabadi, J. (2016). An exploration of the strategic antecedents of firm supply chain agility: The role of a firm's orientations. International Journal of Production Economics, 179, $24-34$.

Hendricks, K.B., Singhal, V.R., \& Stratman, J.K. (2007). The impact of enterprise systems on corporate performance: A study of ERP, SCM, and CRM system implementations. Journal of Operations Management, 25(1), 65-82.

Hidayat, R., Hudha, K., \& Akhmad, S. (2015). Effects of Supplier-Manufacturer Relationships on Supply-Chain Performance of Manufacturing Industries in Indonesia. Makara Journal of Technology, 19(2), 51.

Ismail, MD, Alam, SS, \& Hamid, R. bt A. (2017). Trust, commitment, and competitive advantage in export performance of SMEs. Gadjah Mada International Journal of Business, 19(1), 1-18. https://doi.org/10.22146/gamaijb.22680

Kim, M., \& Chai, S. (2017). The impact of supplier innovativeness, information sharing and strategic sourcing on improving supply chain agility: Global supply chain perspective. International Journal of Production Economics, 187, 42-52.

Kotler, P., \& Keller, K. L. (2006). Marketing Management. 12 ${ }^{\text {th }}$ ed.. France: Edition Pearson Education.

Kwon, IG, Louis, S., \& Louis, S. (2004). Kwon2004. 4-14.

Kwon, IWG, \& Suh, T. (2004). Factors affecting the level of trust and commitment in supply chain relationships. Journal of Supply Chain Management, 40(1), 4-14. https://doi.org/10.1111/j.1745-493X.2004.tb00165.x

Lee, S., Kwon, S., Shin, SJ, Kim, MS, \& Park, IJ (2018). How team-level and individual-level conflict influences team commitment: A multilevel investigation. Frontiers in Psychology, 8 (JAN). https://doi.org/10.3389/fpsyg.2017.02365 
Md Ghazali, N.H. (2016). A Reliability and Validity of an Instrument to Evaluate the School-Based Assessment System: A Pilot Study. International Journal of Evaluation and Research in Education (IJERE), 5 (2), 148.

Mellani, C., Bopeng, L. S., \& Bajari, M. (2019). The Effect of Trust and Information Quality on the Decision to Purchase Airline Tickets on E-commerce Traveloka (Case Study: Traveloka Users in the District of Manokwari). Cakrawala Management Business Journal, 2(1), 252-269.

Kalkan, M. B. Ç., \& Aydın, K. (2020). The role of 4PL provider as a mediation and supply chain agility. Modern Supply Chain Research and Applications, 2(2).

Mukhsin, M. (2020). The Effect Of Commitment Mediation Through The Relationship Betwen Confidence And Performance Supply Chain. Sriwijaya International Journal of Dynamic Economics and Business, 3(4), 329.

Mulyati, E. (2020). Multigroup Analysis in Supply Chain Performance. Journal of Business and Management, 21(2), 100113. https://doi.org/10.24198/jbm.v21i2.466

Nyaga, GN, \& Whipple, JM (2011). Relationship quality and performance outcomes: Achieving a sustainable competitive advantage. Journal of Business Logistics, 32(4), 345-360. https://doi.org/10.1111/j.0000-0000.2011.01030.x

Ryu, H., Kim, JK, \& Baker, JW (2009). A probabilistic method for the magnitude estimation of a historical damaging earthquake using structural fragility functions. Bulletin of the Seismological Society of America, 99(2A), 520-537. https://doi.org/10.1785/0120080032

Sánchez, A. M., \& Pérez, M. P. (2005). Supply chain flexibility and firm performance. International Journal of Operations \& Production Management, 25(7), 681-700.

Sari, SW, Sunaryo, S., \& Mugiono, M. (2018). the Effect of Service Quality on Customer Retention Through Commitment and Satisfaction As Mediation Variables in Java Eating Houses. Journal of Management Applications, 16(4), 593-604. https://doi.org/10.21776/ub.jam.2018.016.04.05

Savira, F., \& Suharsono, Y. (2013). 済 無. Journal of Chemical Information and Modeling, 1(1), 1689-1699.

Shin, Y., Thai, V., \& Yuen, KF (2018). The impact of supply chain relationship quality on performance in the maritime logistics industry in light of firm characteristics. International Journal of Logistics Management, 29(3), $1077-1097$. https://doi.org/10.1108/IJLM-10-2016-0227

Sun, Y., Liu, Z., \& Yang, H. (2018). How Does Suppliers' Fairness Affect the Relationship Quality of Agricultural Product Supply Chains? Journal of Food Quality, 2018. https://doi.org/10.1155/2018/9313068

Sutanto, EM, \& Kurniawan, M. (2016). The impact of recruitment, employee retention and labor relations to employee performance on the batik industry in Solo city, Indonesia. International Journal of Business and Society, 17(2), 375-390. https://doi.org/10.33736/ijbs.531.2016

UK Home Office. (2015). Statistics of Scientific Procedures on Living Animals Great Britain 2014.

Wibowo, MA, Elizar, Sholeh, MN, \& Adji, HS (2017). Supply Chain Management Strategy for Recycled Materials to Support Sustainable Construction. Procedia Engineering, 171, 185-190. https://doi.org/10.1016/j.proeng.2017.01.325

Wu, M., Weng, Y., \& Huang, I. (2012). A study of supply chain partnerships based on the commitment trust theory. Asia Pacific Journal of Marketing and Logistics, 24(4), 690-707. https://doi.org/10.1108/13555851211259098

Xiao, Y., Zheng, X., Pan, W., \& Xie, X.X. (2010). Trust, relationship commitment and cooperative performance: Supply chain management. Chinese Management Studies, 4(3), 231-243. https://doi.org/10.1108/17506141011074129

Wetzels, M., De Ruyter, K., \& Van Birgelen, M. (1998). Marketing service relationships: the role of commitment. Journal of Business \& Industrial Marketing, 13(4/5), 406-423.

Wilding, R., Wagner, B., Gligor, D. M., \& Holcomb, M. C. (2012). Understanding the role of logistics capabilities in achieving supply chain agility: a systematic literature review. Supply Chain Management: An International Journal, 17(4), $438-453$.

Yuan, Y., Feng, B., Lai, F., \& Collins, BJ (2018). The role of trust, commitment, and learning orientation on logistic service effectiveness. Journal of Business Research, 93 (March 2017), 37-50. https://doi.org/10.1016/j.jbusres.2018.08.020

Zhong, R., Xu, X., \& Wang, L. (2017). Food supply chain management: systems, implementations, and future research. Industrial Management and Data Systems, 117(9), 2085-2114. https://doi.org/10.1108/IMDS-09-2016-0391

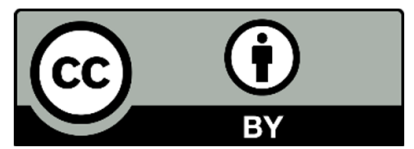

(C) 2021 by the authors; licensee Growing Science, Canada. This is an open access article distributed under the terms and conditions of the Creative Commons Attribution (CCBY) license (http://creativecommons.org/licenses/by/4.0/). 